\title{
Anticipating and Managing Future Trade-offs and Complementarities between Ecosystem Services
}

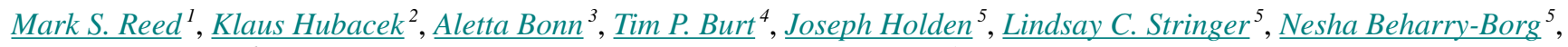 \\ $\underline{\text { Sarah Buckmaster }}^{6}$, Dan Chapman $^{7}$, Pippa J. Chapman $^{5}, \underline{\text { Gareth D. Clay }}^{8}, \underline{\text { Stephen J. Cornell }}^{5}, \underline{\text { Andrew J. Dougill }}^{5}$, Anna

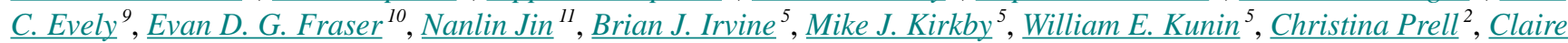

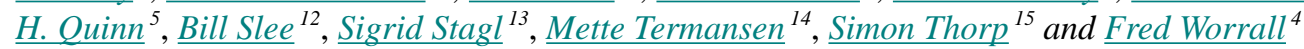

\begin{abstract}
This paper shows how, with the aid of computer models developed in close collaboration with decision makers and other stakeholders, it is possible to quantify and map how policy decisions are likely to affect multiple ecosystem services in future. In this way, potential trade-offs and complementarities between different ecosystem services can be identified, so that policies can be designed to avoid the worst trade-offs, and where possible, enhance multiple services. The paper brings together evidence from across the Rural Economy and Land Use Programme's Sustainable Uplands project for the first time, with previously unpublished model outputs relating to runoff, agricultural suitability, biomass, heather cover, age, and utility for Red Grouse (Lagopus scotica), grass cover, and accompanying scenario narratives and video. Two contrasting scenarios, based on policies to extensify or intensify land management up to 2030, were developed through a combination of interviews and discussions during site visits with stakeholders, literature review, conceptual modeling, and process-based computer models, using the Dark Peak of the Peak District National Park in the UK as a case study. Where extensification leads to a significant reduction in managed burning and grazing or land abandonment, changes in vegetation type and structure could compromise a range of species that are important for conservation, while compromising provisioning services, amenity value, and increasing wildfire risk. However, where extensification leads to the restoration of peatlands damaged by former intensive management, there would be an increase in carbon sequestration and storage, with a number of cobenefits, which could counter the loss of habitats and species elsewhere in the landscape. In the second scenario, land use and management was significantly intensified to boost UK self-sufficiency in food. This would benefit certain provisioning services but would have negative consequences for carbon storage and water quality and would lead to a reduction in the abundance of certain species of conservation concern. The paper emphasizes the need for spatially explicit models that can track how ecosystem services might change over time, in response to policy or environmental drivers, and in response to the changing demands and preferences of society, which are far harder to anticipate. By developing such models in close collaboration with decision makers and other stakeholders, it is possible to depict scenarios of real concern to those who need to use the research findings. By engaging these collaborators with the research findings through film, it was possible to discuss adaptive options to minimize trade-offs and enhance the provision of multiple ecosystem services under the very different future conditions depicted by each scenario. By preparing for as wide a range of futures as possible in this way, it may be possible for decision makers to act rapidly and effectively to protect and enhance the provision of ecosystem services in the face of unpredictable future change.
\end{abstract}

Key Words: blanket bog; ecosystem services; heath; mountain; moorland; payments for ecosystem services; Peak District National Park; upland

\section{INTRODUCTION}

As concerns over global food security and climate change grow, decision makers face increasingly tough decisions about how land should be used (Foresight 2011, Vermeulen et al. 2012). Delivering more food and fiber now might make shortterm economic sense, but without understanding the long-term consequences for the other ecosystem services upon which society depends, decision makers may be unaware of the tradeoffs they are making for future generations. However, identifying likely trade-offs is a challenging task, given the different scales over which many ecosystem services operate, and the unpredictable ways that they are likely to respond to drivers of change in complex social-ecological systems. It is essential to ensure that a payment for one ecosystem service does not inadvertently compromise the provision of other important services. Addressing these challenges is becoming increasingly important as payments for ecosystem services (PES) schemes proliferate internationally (Balmford et al. 2008).

The ecosystem services framework is increasingly being used by policy makers around the world to understand,

\footnotetext{
${ }^{1}$ Birmingham City University, ${ }^{2}$ University of Maryland, ${ }^{3}$ University of Sheffield, ${ }^{4}$ University of Durham, ${ }^{5}$ University of Leeds, ${ }^{6}$ UK Collaborative on Development Sciences, ${ }^{7}$ Centre for Ecology \& Hydrology, Edinburgh, ${ }^{8}$ University of Manchester, ${ }^{9}$ Project Maya Community Interest Company, ${ }^{10}$ University of Guelph, ${ }^{11}$ Brunel University, ${ }^{12}$ James Hutton Institute, ${ }^{13}$ Vienna University of Economics and Business, ${ }^{14}$ Aarhus University, ${ }^{15}$ The Heather Trust
} 
communicate, and manage the benefits that nature provides to society (MEA 2005). The framework is a useful device to systematically consider the likely consequences of a decision on all aspects of nature's "life-support system" (Turner and Daily 2008). However, until recently, using ecosystem services as a framework has largely been heuristic, with no capacity to provide decision makers with quantitative, spatially explicit information about the likely consequences of their actions on multiple ecosystem services as they interact at different spatial and temporal scales. As such, calls for agricultural support to be focused more on the provision of ecosystem services, e.g., debate over the "greening" of the EU's Common Agricultural Policy, have been dismissed by many as unworkable.

With the aid of computer models, it is possible to quantify how decisions are likely to affect multiple ecosystem services in future. Using the outputs of such models, it is possible to begin assessing the magnitude of likely trade-offs, and identify where there may be win-win scenarios where certain land use or management decisions could boost multiple services (e.g., Opdam et al. 2001, Alcamo et al. 2005, Egoh et al. 2010). However, the benefits of such studies can be limited for decision makers, who are rarely involved in the development of relevant scenarios, or in the development of the adaptation strategies that could help them avoid the worst trade-offs that these futures present.

This paper shows how it is possible to identify how different policy trajectories may lead to trade-offs or complementarities between multiple ecosystem services, by combining computer modeling with participation from decision makers. The paper considers the UK uplands as a comparatively simple socialecological system in which there are a relatively limited number of plausible scenarios that are likely to affect ecosystem service provision in future (up to 2030). In conclusion, we offer insights into the sorts of quantitative and qualitative, interdisciplinary, and participatory methods that are necessary to enable decision makers, e.g., policy makers, planners, land owners/managers, to make decisions that can preserve the ecosystem services society depends upon long into the future.

UK uplands are a "land of many uses" (Burt and Hanwell 1992). Traditionally, policy maker and practitioner priorities were related to productive land uses, like sheep grazing or forestry. Increasingly, upland habitats damaged by these historic uses are being restored for carbon storage, water quality regulation, biodiversity conservation, and landscape aesthetics (Bonn et al. 2009). Many ecosystem services provide benefits that wider society does not pay for and yet could not easily survive without or afford to replace, such as drinking water, flood mitigation, or carbon storage (Reed et al. 2009). These "positive externalities" can lead to conflict where their continued provision is at odds with the objectives of land managers, e.g., where the costs of maintaining biodiversity compromise the economic viability of a grouse moor. Equally, "negative externalities" may arise from land uses and management activities that benefit the land managers at the (unpriced) expense of wider society, e.g., water pollution from farming. Market distortions that favor provisioning services, such as the production of food, timber, and wind energy, have been blamed for widespread environmental degradation in uplands, with government subsidies historically encouraging, and occasionally incentivizing overgrazing, drainage, and inappropriate burning regimes (Holden et al. 2007).

The multifunctionality and range of ecosystem services associated with upland landscapes makes them an ideal case study social-ecological system in which we can explore how land use conflict can be resolved and complementarity enhanced. The management of multifunctional land use systems involves multiple objectives, and decisions that inevitably create trade-offs between competing ecosystem services and for the stakeholders responsible for their delivery. The objectives of land owners and managers vary from person to person, from place to place, and from generation to generation. This makes it difficult to predict how future land use decisions might lead to trade-offs between ecosystem services, and to anticipate their likely consequences for society.

This paper focuses on the Dark Peak of England's Peak District National Park (PDNP), but draws from wider research on other UK uplands, to identify lessons that are likely to be relevant for the adaptive management of such dynamic and multifunctional landscapes in a range of other contexts internationally. The paper brings together evidence from across the Rural Economy and Land Use Programme's Sustainable Uplands project (www.sustainableuplands.org/) for the first time, with previously unpublished model outputs relating to spatial runoff patterns, agricultural suitability, biomass production, fractional heather and grass cover, heather age, and accompanying scenario narratives and video. The paper develops a methodology that can be used to show quantitative and spatially specific ecosystem service outcomes in response to policy scenarios, and addresses the following questions: (1) What externalities are associated with upland ecosystem services under different future scenarios? (2) How can we minimize trade-offs and enhance complementarities between different land uses and management practices to secure future provision of ecosystem services from uplands?

\section{RESEARCH DESIGN}

\section{Methods}

The Sustainable Uplands project was designed to combine knowledge from local stakeholders, policy makers, and social and natural scientists to anticipate and sustainably manage 
rural change in UK uplands. In summary, the methodology consisted of the following steps:

1. Better understand stakeholder priorities and relationships through stakeholder analysis and social network analysis. Stakeholder analysis was conducted through an initial workshop with cross-sectoral stakeholders, adapting an interest-influence matrix (c.f. Eden and Ackerman 1998) with additional columns added to capture more detailed information about the nature of different stakeholder interests and influence, their relationships with one another, and contact details (Dougill et al. 2006, Reed et al. 2009). This was followed up with a sample of interviews with key individuals identified during the stakeholder analysis workshop and their contacts to categorize stakeholders. This led to the following groups being identified: hill farmers, sporting estates, water companies, forestry, conservation organizations, recreation/tourism, and statutory bodies. Further information about relationships between these stakeholders was gathered using Social Network Analysis (Prell et al. 2008, 2009, 2010). This information was used to select a small, but well-connected, trusted, and broadly representative group of stakeholders to work with during the next step. By working with wellconnected individuals who were considered by others in the network to be trustworthy, it was hoped that new ideas and attitudes emerging from the research process would diffuse to a much larger network of stakeholders than was possible to work with directly;

2. Understand current and future perceived challenges and opportunities in the upland system through a combination of literature review, semistructured interviews, and site visits, where a small group of stakeholders and researchers, selected from the stakeholder analysis and Social Network Analysis in the previous step, shared their knowledge about how the system would be likely to respond to anticipated changes. Qualitative data arising from interviews and site visits were analyzed using Grounded Theory Analysis (Glaser and Strauss 1967);

3. Develop a conceptual model of the upland system using themes that emerged from the analysis of interviews and site visits, supplemented with information from published literature, and integrated using Vensim software (Prell et al. 2007) to connect drivers of change with system components and outcomes. Figure 1 shows a submodel from this conceptual model;

4. Create draft scenarios by tracing drivers of change through the system as they affect different system components to create draft narratives describing the system components that might be affected by different drivers of change, leading to various outcomes (Reed et al., in press);
Fig. 1. Map of Peak District National Park showing the Dark Peak area (shaded).

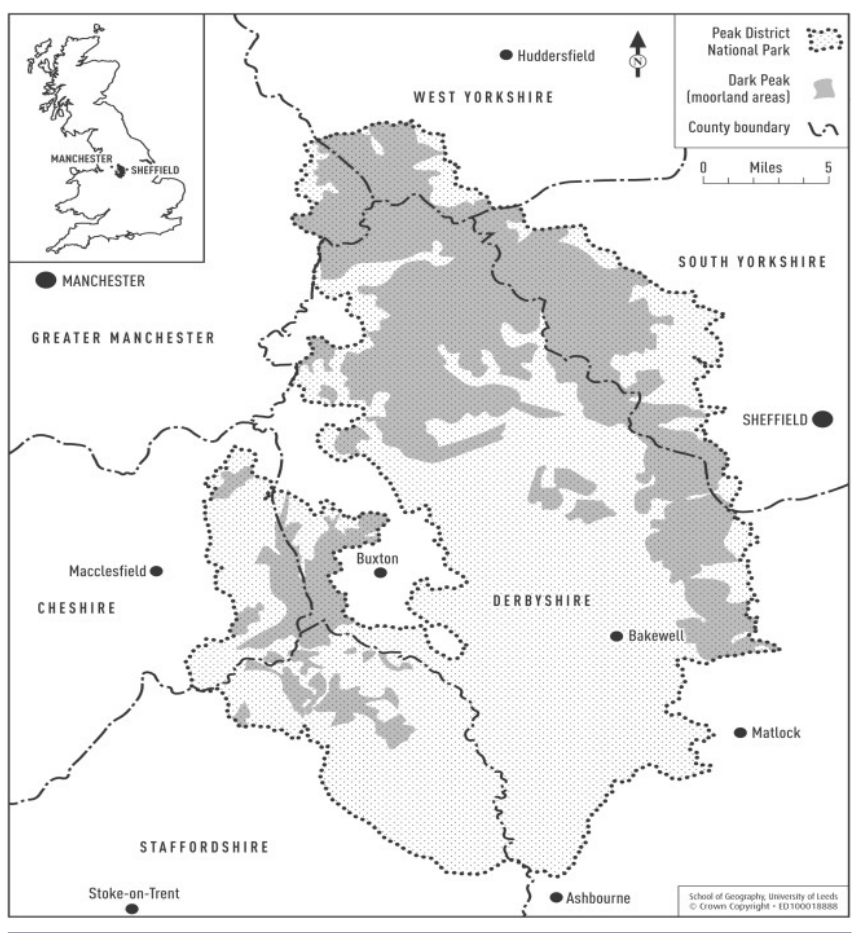

5. Refine and prioritize draft scenarios. Draft scenarios developed in the previous step were presented at a stakeholder workshop. Draft scenarios were subdivided into a number of components, and participants were asked to evaluate: (i) the likelihood that each component of the draft scenario would happen; and (ii) if likely to happen, the extent to which each component contributed to a major impact, either positive or negative. New components were added to draft scenarios where necessary, and parts of scenarios that were deemed unlikely to happen and/or unlikely to have a major impact were removed from draft scenarios. The same exercise was then repeated for each revised scenario, consisting of all the components that made it through from the previous exercise, ranking each of these revised scenarios in relation to their likelihood and if they were to happen, the likely magnitude of their impact (for more details, see Hubacek and Reed 2009; Reed et al., in press). This ranked list of scenarios was then discussed, and top ranking scenarios were further explored using processbased computational models in the next step;

6. Investigate scenarios in greater detail using computational, process-based models to explore details, feedbacks, and potential interactions between scenarios, to identify possible trade-offs between ecosystem 
services that may be important for future planning. To do this, a number of spatially explicit, process-based models, covering land manager behavior, vegetation cover and type, particular bird species of interest to land managers and conservationists, carbon dynamics, and water quality were developed to assess the likelihood that different scenarios would lead to an increase in the provision of certain ecosystem services at the expense of others (trade-offs) or lead to win-win improvements in multiple ecosystem services (complementarities). A spatially explicit model of moorland vegetation dynamics and management decisions about sheep grazing and heather burning in the Dark Peak of the PDNP was developed (Chapman et al. 2009a, 2010). Competition between dwarf shrubs, bracken, and graminoids was mediated by grazing, dwarf shrub age (determined by burning rotation), and environmental gradients, and management decisions were dependent upon vegetation cover. The model was parameterized through a choice experiment with land owners and managers in the Dark Peak of the PDNP to reveal preferences for alternative production strategies and the extent to which these choices were influenced by their ecological and policy context (Jin et al. 2009). Linked to this, a stochastic model of Red Grouse (Lagopus scotica) dynamics was developed to examine how interactions between territoriality, productivity, harvesting, and other environmental factors influence Red Grouse population cycles (Chapman et al. 2009b). The PESERA model (Kirkby et al. 2008) was used to assess how simulated changes in management and vegetation cover, type, and biomass would influence runoff patterns and contribute to the delivery of sediment and nutrients downstream. Agricultural suitability was considered as a combination of mechanical limitations and climatic potential. Carbon fluxes from peat soils, including all carbon uptake and release pathways, both fluvial and gaseous, were modeled by Worrall et al. (2007, 2009), run for a decade from 1997-2006, and applied to an area of $550 \mathrm{~km}^{2}$ of upland peat soils in the Dark Peak of the Peak District;

7. Communicate findings. Model outputs were combined with insights from semistructured interviews that could not be modeled to create scenario narratives. These were communicated to workshop participants in the following step using short films. Boxes 1 and 2 provide scenario narratives that were adapted to create film scripts. These narratives are illustrated with model outputs in Boxes 1 and 2 , and links are provided to the short films. Film was chosen as a medium in response to feedback from local stakeholders, who provided feedback throughout the film development process. As such, this differs from "participatory video," which relies purely on local knowledge, usually shot by local communities themselves (e.g., Braden 1999, Kindon 2003, White 2003). It also differs from other film outputs from other scenario projects that tend to rely mainly on scientific knowledge (e.g., Nakicenovic et al. 1998, IPCC 2000, Morris et al. 2005, Mensonides et al. 2008). As such, the combination of local and scientific inputs gives the films a relevance and resonance that they could not otherwise have achieved, while being based on a rigorous evidence base. To use video in a more interactive way, the project developed an interactive website (www.ouruplands.co. uk) to communicate findings from the research through videos of project team members, and to share perspectives between upland stakeholders and members of the public. Key messages from the scenarios were also packaged for more generalist audiences as an illustrated children's fairytale and a music video (see Appendix);

8. Use films to discuss innovative ways that would enable stakeholders to respond to each scenario. Where possible, models were used to evaluate adaptation strategies that had been suggested during interviews, site visits, and workshops, and provide feedback to stakeholders about how likely they would be to work. These findings were discussed in a final stakeholder workshop in which participants were shown scenario films and asked to suggest additional adaptation strategies (Table A1.1).

\section{Case study context}

Although the project worked in three sites in the UK, this paper focuses primarily on data from the Dark Peak of the PDNP. This region is typical of many UK uplands and marginal mountain areas of Europe that are facing pressures resulting from demographic change, policy reform, and environmental problems, such as soil erosion, biodiversity loss, and climate change.

The Dark Peak area of the PDNP was chosen for its diversity of land use activities, i.e., conservation, farming, tourism, water harvesting, shooting, and fishing, and the range of social, economic, political, and environmental pressures it faces. It is situated at the southernmost extension of the South Pennine upland rangelands, between two large cities (Fig. 2). With $500 \mathrm{~km}^{2}$ of open access land and more than 10 million leisure visits per year, the PDNP is Britain's most visited National Park (Peak District National Park Authority 2004). The PDNP contains a number of villages and towns, but only $17.2 \%$ of its 38,000 population live in the Dark Peak area (Office for National Statistics 2003). The livelihoods of PDNP residents are more reliant on agriculture, game birds, and tourism than the national average (Office for National Statistics 2003). Most moorland is privately owned and managed primarily for a combination of Red Grouse and sheep production. 
Fig. 2. Conceptual submodel of socioeconomic and biophysical processes related to burning management in the uplands of the Peak District National Park, showing (inset) how many of the processes represented in this model interact at different spatial and temporal scales $(\mathrm{CAP}=$ Common Agricultural Policy reform; $\mathrm{DOC}=$ Dissolved Organic Carbon BAP $=$ Biodiversity Action Plan; adapted from Prell et al. 2007)

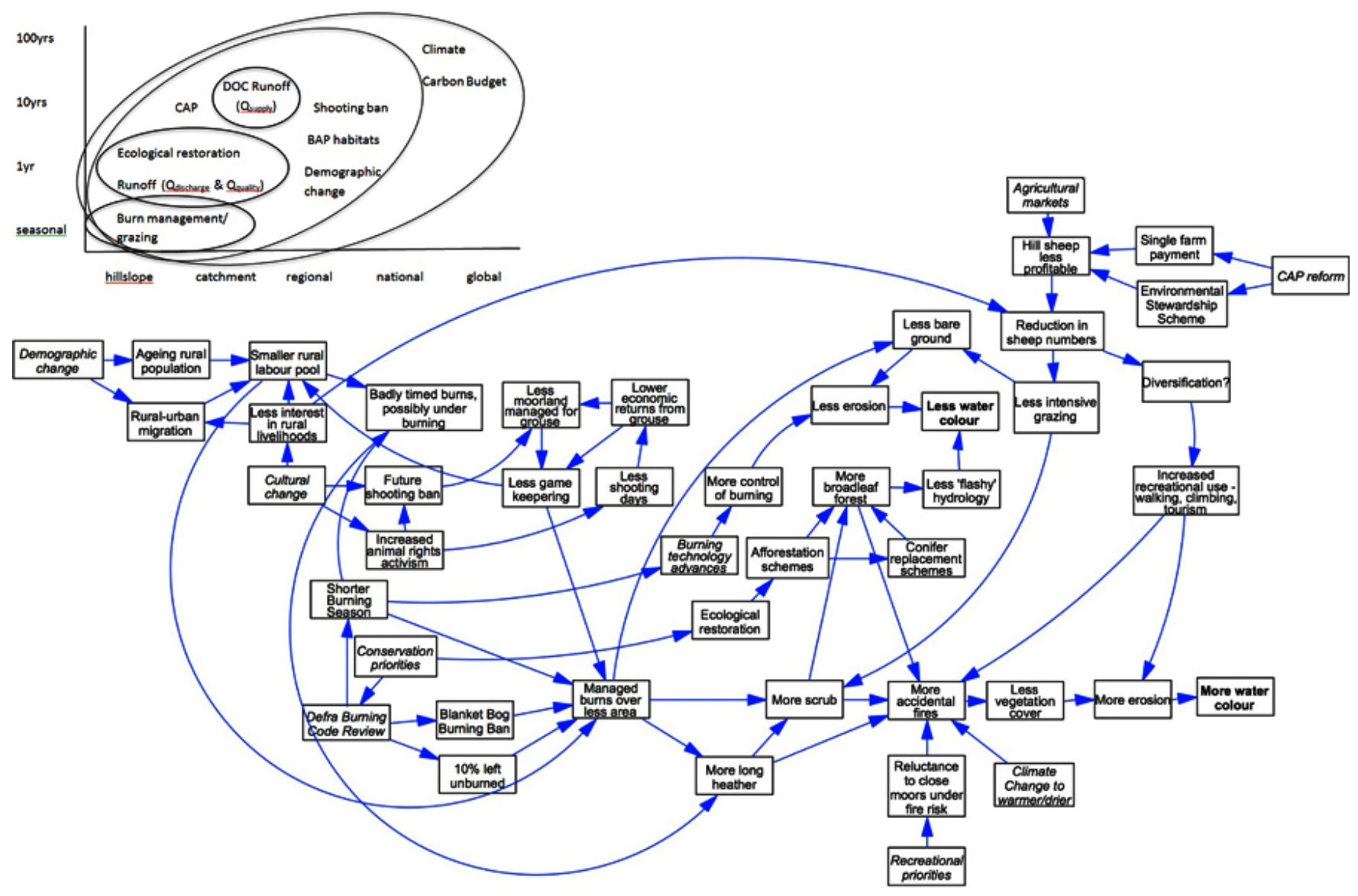

Box 1: What if Britain's hill farmers managed the land for wildlife and carbon?

\section{[Link to film: http://youtu.be/bKo3IPYBAII]}

Sheep are rapidly disappearing from Britain's hills; why is this happening and what does it mean for the land? Changes in agricultural subsidies are forcing many farmers to take tough decisions and climate change could add to the pressures. Therefore, if the sheep do disappear, will they be replaced by Red Grouse? That could be true on some estates, with controlled burning used to manage the land. However, some land managers fear that shooting will itself come under fire, because of short-term fears about bird flu and longer term changes in public attitudes toward hunting that could see a future ban on killing wild birds. Whether we lost sheep or game or both, many see a future in which land managers increasingly become carbon and wildlife managers.
Unless land managers are paid to graze and burn these environments to prevent scrub like young birch (Betula) trees and gorse (Ulex) coming in, some areas may end up being left to go wild. This would probably be the least productive, highest, and most remote land. It would lead to more areas becoming dominated by heather (Erica) at the expense of grass. Figure 3(i) shows the current area dominated by heather in purple. Figure 3(ii) shows that under current management the heather fraction, where heather currently exists, increases by 2030 at the expense of grass. Highly managed areas remain relatively stable. Figure 3(iii) shows a greater increase in heather fraction by 2030 if we remove management. Although this might sound good for Red Grouse, who depend on heather to nest and feed, more and more of the heather will be too old to actually feed them. Therefore, there is the possibility that very little of the heather in the Peak District National Park would actually be of any use for Red Grouse. In the drier parts, the removal of management would lead to an invasion of scrub and eventually forest. Figure 4 shows the driest parts of the Peak District in light blues and greens 
Fig. 3. Heather fraction and changes between 2009-2030: (i) current heather fraction; (ii) future heather fraction under current management; and (iii) future heather fraction in response to the "farmers as wildlife and carbon managers" scenario.
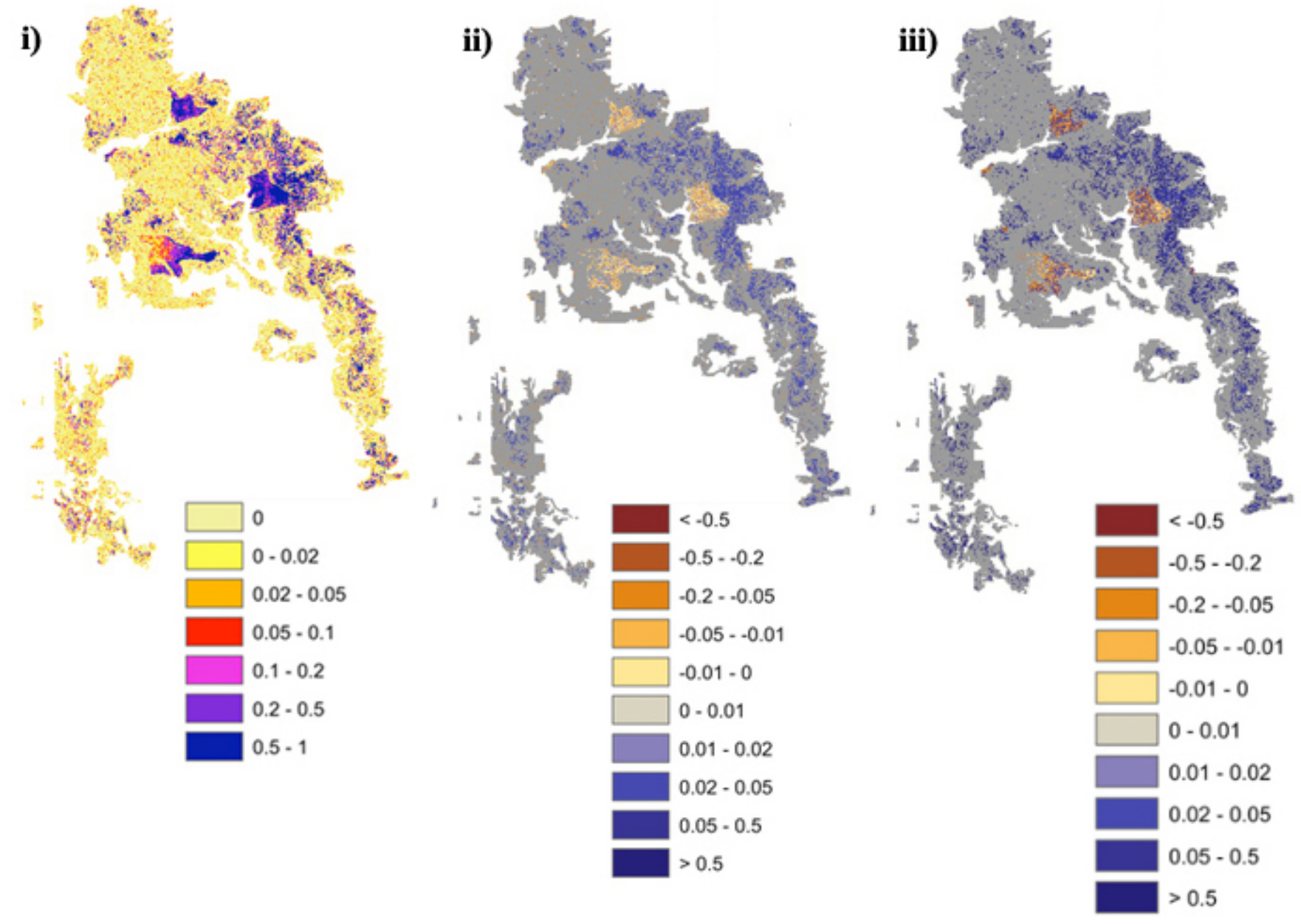

where scrub would first appear in the east. As a result, it is likely that government would fund the creation of fire-breaks to reduce the risk of catastrophic wildfires. In the shorter term this could mean more different types of plants and animals, but looking further ahead, it would almost certainly lead to a reduction in the prevalence of important habitats and species (such as Dunlin [Calidris alpina] and Golden Plover [Pluvialis apricaria]).

Climate change will present further challenges. Species will have to move further north and higher up hills to maintain the sort of living conditions they are used to. Although some, such as the Black Grouse (Lyrurus tetrix), would benefit from more trees, it is more efficient to conserve these species by actively managing forests than by just allowing the land to go wild. Also, although a few species might benefit from this new scrubby landscape, the majority of the people who live, work, and play in our hills would not be happy about it. Most of those who visit these environments are attracted by their uninterrupted purple-tinted vistas and unique wildlife, and do not want bushes and trees obscuring their view.
However, it is not all doom and gloom. Leaving the hills to go wild would help us stop losing carbon from the soil. Figure 5(i) shows how much carbon we are currently losing from the soil in red. If we were to stop grazing and burning and leave the land to go wild, Figure 5(ii) shows how the soil would start to absorb and store carbon from the atmosphere. However, in the less remote, lower areas, which are less likely to be abandoned altogether, it may be possible to actively manage the land for carbon. This may actually be more profitable than managing for sheep or game if the public are prepared to pay land managers to offset their carbon emissions. We already know that blocking drainage ditches and gullies, and revegetating bare and eroding peat can prevent huge amounts of carbon being lost from the hills, and store more carbon in the soil as new layers of peat are laid down year after year in future. Reducing the amount of managed burning may also help in some areas. In fact, we calculate that if all the areas of peat in our hills were restored and in pristine condition they could soak up $2 \%$ of current UK vehicle emissions every year. If we did everything we could to restore damaged peats to pristine condition, Figure 5(iii) shows how we could actually absorb and store 
even more carbon than we could if we just let things go wild. However, the benefits would not stop here; restoring damaged moorland could bring back important wildlife, reduce the risk of catastrophic wildfires, produce cleaner water, protect fish populations downstream, and may even in some cases reduce flooding in towns and cities. As long as the kind of weather we get under a future climate does not dry the soil out too much, blocking drainage ditches may also reduce the spread of scrub and trees by making the soil too wet for trees to grow.

We calculate that if members of the public would be willing to pay around $£ 25$ per tonne of carbon to support all the additional benefits you get from moorland restoration (that's little more than $£ 10$ for a flight from Aberdeen to London), you could pay back restoration costs within 30 years, which makes it a good alternative to forestry schemes. Now we just need to work out where is best to do this to avoid creating the greenhouse gas methane at the same time, which could counteract the climate benefits.

Of course even if such a scheme was realized and the price of carbon remained buoyant, there would be major changes for upland communities if they became carbon and wildlife managers. There could be significantly fewer, but probably larger, hill farms, with those who remain in the hills increasingly having to look for alternative ways to make money, for example through tourism, and direct marketing of local specialist products like "fell-bred" lamb. Deer management may benefit from an increase in hill forests, but Red Grouse managers might have to pay grazers or burn more land to keep the trees at bay.

Fig. 4. Ratio of average annual rainfall and potential evapotranspiration in the Peak District National Park, showing areas in light blue and green where soils tend to be drier toward the east of the park, areas where scrub and forest are most likely to encroach in the absence of management for sheep and grouse.

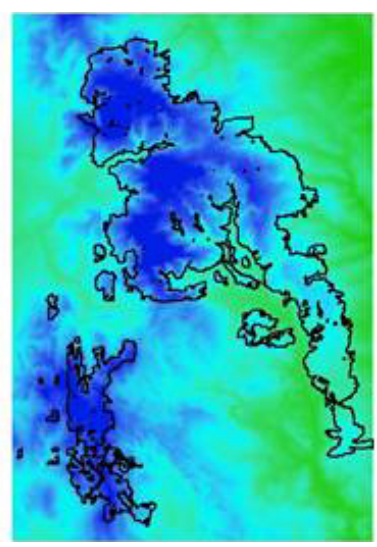

\section{Box 2: What would improving UK food security mean for our hills?}

[Link to film: http://youtu.be/KduOlzABanI]

Recent rises in food prices have made us all aware how important it is to ensure daily essentials are widely available and affordable long into the future. As a result, governments around the world, including the UK's, are increasingly interested in improving food security. This could mean changes in the uplands.

If we want to become more self-sufficient in food production, we will need to use more land, and we will need to manage the land we are already using more intensively. We would see many more sheep on the hills than we do today, and in some places, a mix of sheep and cattle. But there could be far more significant changes in some upland areas.

There are many parts of the country that were farmed in the past and could be used again to provide food. If we are committed to feeding ourselves, we may need to plow up some of the more suitable high ground to grow crops. Figure 6(i) shows the parts of the Peak District National Park that would be most suitable to grow crops. This shows that as the climate changes, it may be possible to cultivate much more land than we could today.

In many parts of the country, our hills would have been tilled in the distant past, but not within living memory. With a bit of effort, for example liming the soil and using trees as windbreaks, it may just be possible to successfully implement such a plan.

However, providing more homegrown food in this way will come at a price. First, the extra grazing and cultivation would mean a lot less vegetation on the hills, perhaps as little as $10 \%$ of the potential biomass (Figure 6[ii]). This vegetation slows the rate at which rain reaches streams and rivers; without it, much more water will reach our rivers much faster. Figure 6(iii) shows current runoff compared to the amount of water we would expect to see running off the hills under this scenario by 2030; more blue means more water coming off the hills. This will increase the risk of flooding in towns and cities downstream. We are already struggling to meet EU demands to clean up our watercourses, but the extra fertilizers washing into streams and rivers from this new arable land would make this job almost impossible. It would also change the color of the water coming out of our hills, making it even harder for water companies to get rid of the brown color they currently spend millions trying to remove. Because more water would run off the hills faster, more sediment would wash down our rivers, covering salmon spawning beds and clogging up reservoirs more quickly than ever. If cropland were created outside the areas our maps suggest would be most suitable, there would be far more soil erosion, which would lead to more problems with sediment. By increasing the numbers of livestock in the hills, we risk changing the ecological balance between the wild species of plants and animals, many of which are internationally important. However, perhaps the most significant consequence could be the impact on the climate system. The peat deposits in our hills are the largest store of carbon in the country, holding more than all the carbon stored in the forests of Britain and France combined. If enough of this washes down our rivers and ends up in the atmosphere 
Fig. 5. Carbon budget in Peak District National Park showing (i) current carbon budget (-62 tonnes $\mathrm{CO}_{2} \mathrm{eq} / \mathrm{km}^{2} / \mathrm{yr}$ ); (ii) carbon budget in 2030 under active management for carbon, including various combinations of cessation of grazing and burning, blocking drainage ditches and gullies, and revegetation of bare and eroding peat soils (-160 tonnes $\mathrm{CO}_{2} \mathrm{eq} / \mathrm{km}^{2} / \mathrm{yr}$ ); and (iii) carbon budget in 2030 with cessation of grazing and burning (-117 tonnes $\mathrm{CO}_{2} \mathrm{eq} / \mathrm{km}^{2} / \mathrm{yr}$ )

ERRATUM: In the original version of this manuscript items (ii) and (iii) were reversed. The correction was made on 9 April 2013.
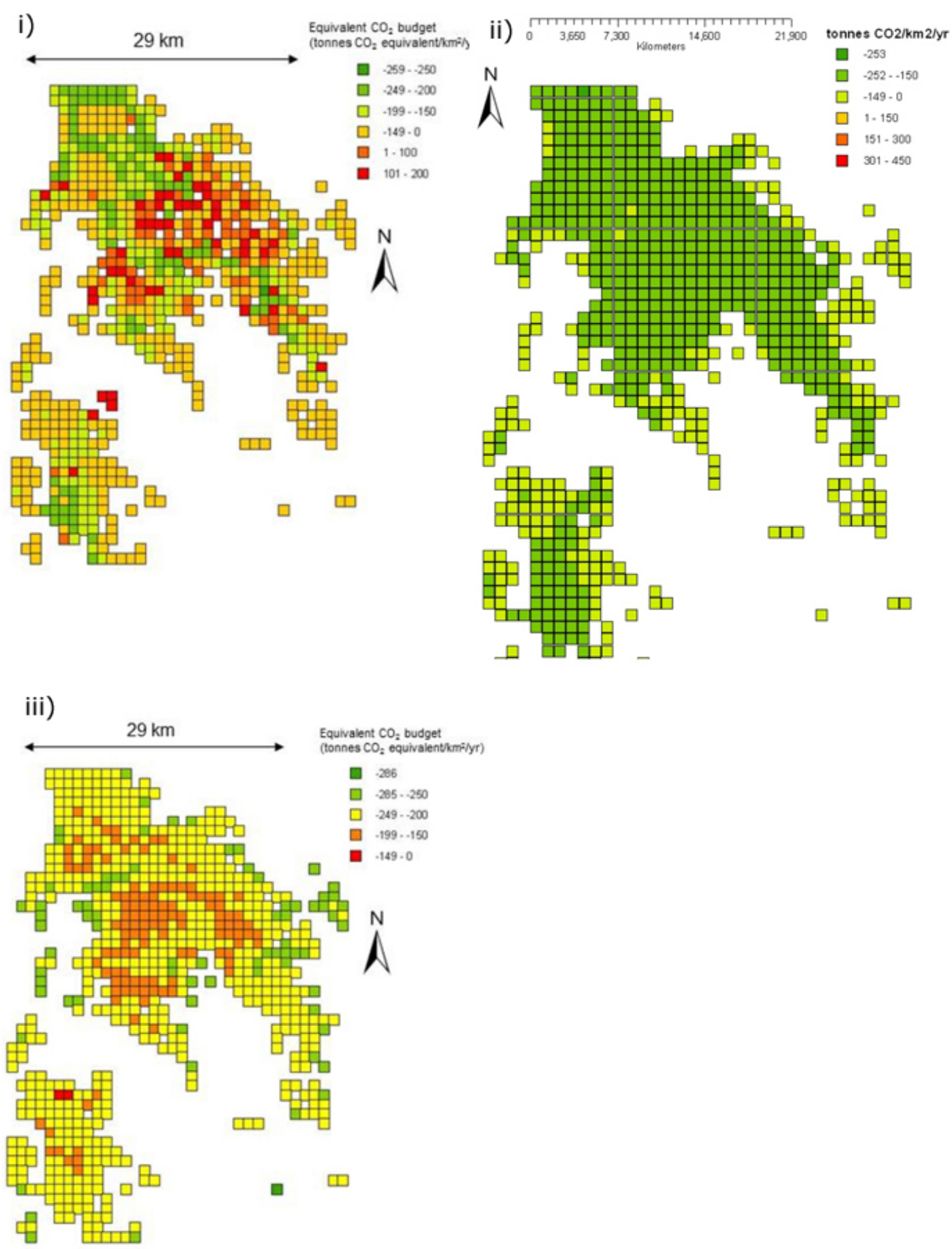
as carbon dioxide, it could exacerbate climate change, which in turn would warm up the soil, releasing yet more carbon, i.e., a vicious cycle.

The Dark Peak received international conservation status as part of the South Pennine Moors Special Area of Conservation (SAC Habitats Directive 92/43/EEC) and Special Protected Area (SPA, Birds Directive 79/409/EEC) and the majority of the area is designated as Sites of Special Scientific Interest (SSSI; a national conservation designation). Conservation competes with multiple demands on the landscape including water harvesting, recreation and tourism, agriculture, forestry, and game management, because each is managing the land to meet different priorities, yet management decisions have effects for other groups. For example, English Nature (2003) attributed a high proportion of Peak District's designated SSSIs being in "unfavourable condition," predominantly due to a combination of overgrazing and "inappropriate" burning, some of which has been reclassified as "unfavourable recovering" condition through extensive restoration efforts. Managed burning is used in the area to create a mosaic of heather stands to maximize Red Grouse populations (Holden et al. 2007). Sheep grazing levels have declined significantly in recent decades, mainly as a result of Environmentally Sensitive Area agreements (Dougill et al. 2006).

\section{RESULTS AND DISCUSSION}

We reflect on the use of film to integrate local and scientific knowledge, enabling stakeholders and researchers to work together to identify relevant adaptations. We also explore the likely externalities associated with two contrasting policy scenarios, based on either extensification or intensification of land use and management in uplands, and identify likely tradeoffs between ecosystem services. The scenarios are constructed using narratives, illustrated with short films (Boxes 1 and 2). It concludes by briefly exploring a range of future policy innovations that could pay for important positive externalities, to reduce conflict and exploit complementarities between land uses in UK uplands.

\section{Integrating knowledge through film}

The filmmaking process enabled knowledge to be integrated from a range of sources. It was possible to combine knowledge from interviews, workshops, and site visits that was implicit (made explicit through the interview or workshop process), informal (rarely codified or written down), local, contextspecific (often site or even hillslope specific), and experiential "know-how," e.g., knowledge of good practice moorland burning, with knowledge from existing literature and the construction of models that was more explicit, formal, generalizable, processed-based "know-why" (c.f. Raymond et al. 2010). The knowledge integration process that culminated in the films, started with scenario workshops in which stakeholders combined local knowledge extracted from interviews, workshops, and site visits, with knowledge from literature and models to refine and rank scenarios (Reed et al., in press). This information was then used to construct narratives (Boxes 1 and 2), which were then illustrated and communicated in the films. The process of identifying adaptations to the scenarios then took place in response to the films (source a, Table A1.1). As such, although primarily based on the knowledge of participating stakeholders, the adaptations were built upon the combination of qualitative local knowledge and quantitative model outputs that had been captured in the films. In addition to these adaptations, which arose primarily from stakeholders, other adaptations were suggested by the research team and explored in collaboration with stakeholders alongside the development of scenarios, e. g., using carbon markets to pay for peatland restoration (Worrall et al. 2009).

Film was chosen in preference to the use of GIS and model outputs in map or graph form, or via a user interface, in response to suggestions from the project's Stakeholder Advisory Panel. This group had concerns about the abstract nature of such outputs, and worried that some stakeholders might find them difficult to understand. They suggested that film, by contrast, had the capacity to inform everyone, irrespective of their formal educational status. This was important, because stakeholders working with the project ranged from those with PhDs who were very comfortable using computers, to those who were illiterate and did not use computers. Therefore, the use of film enabled the project to communicate research findings to all stakeholders, enabling adaptations to be built on the widest possible knowledge base. By enabling everyone to discuss adaptations on the basis of a similar understanding of the project's research findings, it was also possible to reduce power imbalances that had previously arisen within the group between those with and without formal education.

The use of films also enabled the project to overcome issues of visual bias that are inherent in many scenario visualization techniques based on mapping and graphics (c.f. Reed et al. 2009). Such biases occur when scenarios focus primarily on material that can readily be represented in maps or graphics, e.g., tree cover or erosion, at the expense of material that is harder to represent visually, e.g., cultural change or soil chemical degradation. Using film, it was possible to map some model outputs, e.g., carbon sequestration and storage, and use visual metaphors to represent other material, e.g., stream water to represent increased overland flow or images of villages to represent cultural change. Because the narratives in Boxes 1 and 2 were based strictly upon research findings, they remained quite technical, but viewer interest was maintained 
by interspersing the narrative with stakeholder interviews in the films. To ensure the films were accessible to all stakeholders, they were distributed via DVD as well as uploaded to YouTube, where they were viewed over 1000 times in the first year, providing far greater accessibility to research findings than would be possible through many other media.

\section{Scenarios}

Boxes 1 and 2 present the narratives and accompanying films that were developed to communicate scenarios. They draw on material from all three study sites, and so are framed nationally, giving them greater policy relevance. However, for the purposes of this paper, illustrations have been drawn from the Dark Peak of the Peak District National Park. Although the narratives are strictly based upon research findings, some simplifications were necessary for communication purposes. For example, there are no caveats about how variations in climate and plant community composition across the country may influence carbon sequestration and storage potential. Also, it should be noted that because the projections for 2030 rely on the system equilibrating to the modified environment by then, lags in ecosystem responses will mean the actual situation is likely to be somewhere between what we observe now and what is shown in the scenarios. Box 1 extrapolates a widely perceived current policy trajectory toward the extensification of land use and management in uplands, which, it is believed, may lead to the restoration of land degraded by intensive management, that had previously led to drainage and bare/eroding peat, and the removal of other areas from active management altogether. Stakeholders interviewed for this research emphasized that there was no single approach to extensification, or "rewilding" as it was often described. Instead, there was a spectrum of likely approaches that could occur together, ranging from an expansion of the least intensive current practices, e.g., restoration, to complete land abandonment with no active management (c.f. Deary 2012). A range of policy triggers could cause this scenario, including changes to the total amount of agricultural payments available via the Common Agricultural Policy, changes to the configuration of such payments, i.e., greening payments to focus on the provision of ecosystem services, a ban on hunting wild birds, or changes in policy that would enable more land managers to pay for restoration via PES, e.g., for the associated carbon or water quality benefits of restoration.

Continued extensification of land use and management may lead to a number of important negative externalities that could have significant implications for the future provision of multiple ecosystem services from uplands (as described in Box 1):

1. Provisioning services: a significant reduction in sheep and Red Grouse production, with effects for upland communities whose livelihoods currently depend upon these activities in the Dark Peak of the PDNP;

2. Regulating and supporting services: extensification of land use, e.g., reduction in burning, might improve the condition of blanket bog habitats. However, because many blanket bog areas in the Dark Peak of the PDNP have been damaged in the past, they have low water tables and without restoration efforts to raise water tables, these might not recover. A lack of management on dry heath and acid grassland habitats might result in an increase in scrub and eventually forest. This might temporarily increase the risk of wildfires, which could damage soils and release the carbon they contain, potentially leading to a positive feedback with climate change; and

3. Cultural services: increased wildfires might degrade important habitats. Heather density increases by 2030 as a result of reduced levels of managed burning and grazing, but much of the heather would be old growth, and without the mosaic of different-age-stands currently created by managed burning, little of this new heather would likely be useful as habitat for Red Grouse (Fig. 3). A significant increase in vegetation height would probably favor species like Reed Buntings (Emberiza schoeniclus schoeniclus), an IUCN "Red List" species, and Snipe (Gallinago gallinago; "Amber List") at the expense of species like the Special Protection Area (SPA) designated species, Golden Plover (Pearce-Higgins et al. 2006). A significant increase in heather cover could reduce the abundance of Skylarks (Alauda arvensis; Red List) and Meadow Pipit (Anthus pratensis; Amber List), and a significant reduction in grass cover could reduce the abundance of Golden Plover, Dunlin (Amber List and SPA designated), Snipe, and Reed Buntings in the Dark Peak (Pearce-Higgins et al. 2006). In drier areas, scrub and forest may gradually replace habitats and associated species that are internationally significant and protected under various statutory designations. Although this scenario may create habitats suitable for certain important species, like the Red List species Black Grouse, this may be at the expense of the majority of habitats and species that are currently the focus of national and international statutory designations in the uplands. Those who visit uplands for recreation tend to value their uninterrupted views and unique habitats and wildlife (van der Wal et al. 2011), which would be compromised by scrub and forest.

A number of benefits would be associated with managing uplands for carbon through active restoration, typically associated with the extensification scenario. Figure 5 shows that compared to the current carbon budget (-62 tonnes $\mathrm{CO}_{2} \mathrm{eq} /$ $\mathrm{km}^{2} / \mathrm{yr}$ ), the carbon budget in 2030 with cessation of grazing 
and burning would be -117 tonnes $\mathrm{CO}_{2} \mathrm{eq} / \mathrm{km}^{2} / \mathrm{yr}$, and the carbon budget in 2030 under active management for carbon, including various combinations of cessation of grazing and burning, blocking drainage ditches and gullies, and revegetation of bare and eroding peat soils would be -160 tonnes $\mathrm{CO}_{2} \mathrm{eq} / \mathrm{km}^{2} / \mathrm{yr}$. This may partly be due to the increasing value placed on carbon in the context of efforts to mitigate climate change. A study commissioned by the UK Department for Environment, Food and Rural Affairs (DEFRA) on the ecosystem services of peat, that included the Dark Peak of the PDNP as one of its case studies, found carbon storage was the only ecosystem service ranked in the top three most important services by stakeholders in all four case studies (Bonn et al. 2010). Similarly, Christie et al. (2010) found stakeholders rated carbon storage, along with water provision, as the most highly valued service provided by conservation of blanket bogs under the UK's Biodiversity Action Plan.

Box 2 focuses on policies that lead to intensification of land management, mainly livestock intensification, but potentially some conversion to arable use, to meet growing demands for UK self-sufficiency in food production. This scenario is based on a future where food prices have become prohibitively high, because of population growth and growing appetites of the emerging middle classes in the developing world, combined with a contraction in global production because of the effects of climate change. This may result in policies and/or market incentives to bring more marginal land into intensive production. Figure 6(i) shows that this might be facilitated by increases in agricultural suitability in uplands due to climate change by 2030. Grazing and cultivation could lead to a reduced biomass cover, around $90 \%$ of the potential biomass (Fig. 6[ii]). This would lead to an increase in runoff by a factor of two (Fig. 6[iii]). More intense grazing and arable production could release carbon, and reduce water quality through erosion and Cryptosporida contamination, with associated water treatment costs for water companies, and potentially increase runoff generation and peak flows due to shorter swards. Plowing, even where feasible, could increase the delivery of sediment and nutrients downstream, with consequences for reservoirs and fish spawning beds. Although deemed less likely than other scenarios by most stakeholders, this scenario is considered highly plausible and, if it were to happen, of major significance for the future provision of ecosystem services from uplands (Reed et al., in press).

A reduction in the abundance of a range of species of conservation concern is a negative externality of both scenarios, and may be a flashpoint for future conflict in UK uplands. Interestingly, there is evidence that existing conflicts in uplands revolve around biodiversity conservation issues. Evidence from a Social Network Analysis of upland stakeholders in the PDNP suggests that a number of cliques exist between stakeholder groups who communicate regularly
Fig. 6. Changes in area of land suitable for arable agriculture, annual runoff, and vegetation cover under the "food secure future" scenario, showing (i) Dark Peak uplands suitable for arable agriculture in 2000 and 2030; (ii) vegetation biomass in 2009 and 2030 showing $10 \%$ of potential biomass in 2030; and (iii) annual runoff in 2009 and 2030.

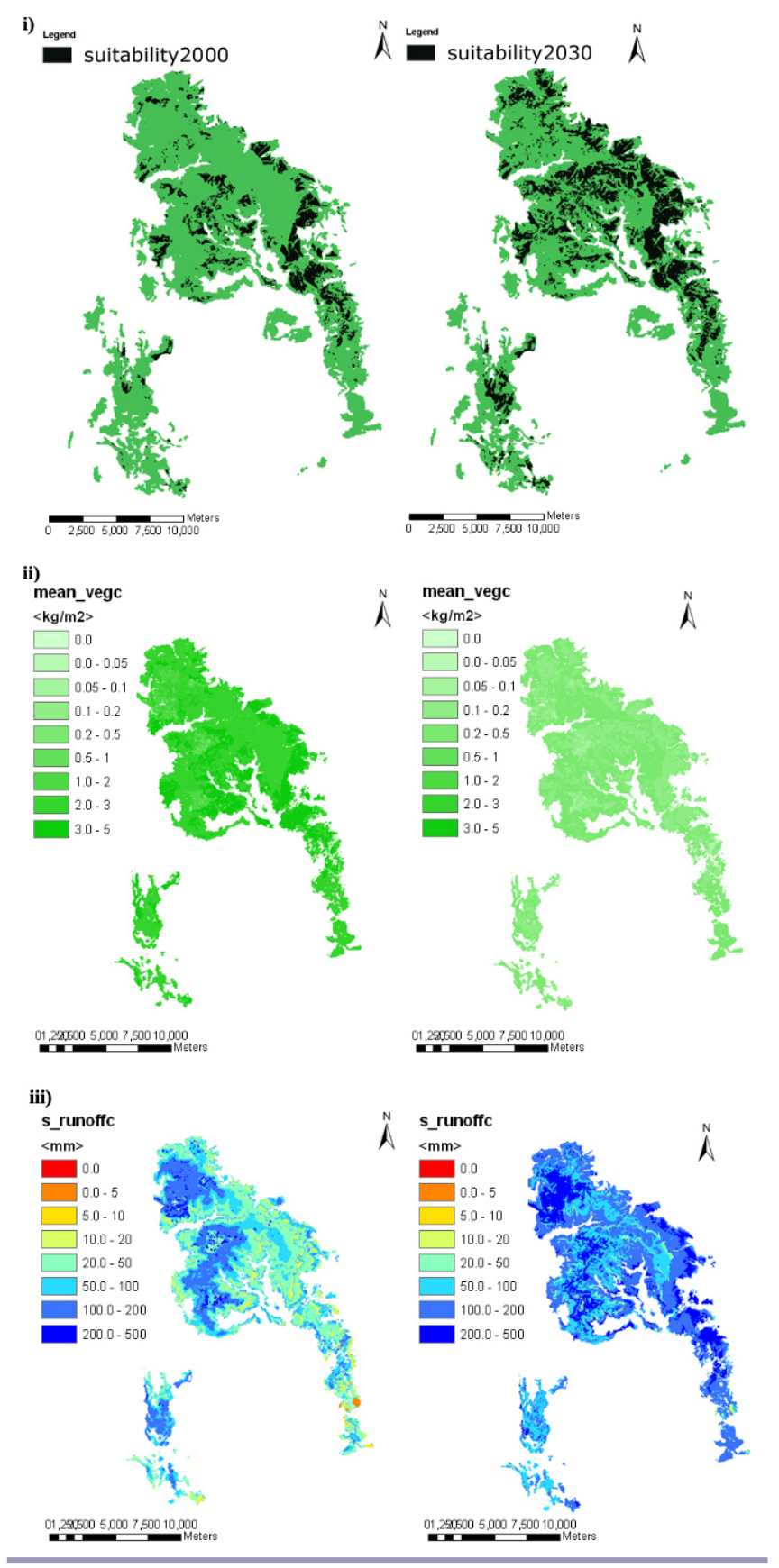


and trust one another (Prell et al. 2008, 2009). This work identified one clique as those with interests in agriculture and grouse moor management and another between conservation and water companies, with little communication or trust between each of these cliques. This dividing line corresponded with the terms of an argument, explored through semistructured interviews, between members of each clique over the extent to which moorland burning should be regulated. On one side, conservationists and water companies wanted tighter regulation to prevent "inappropriate" burning on some habitats and reduce water discoloration in upland streams. On the other side, farmers and grouse moor managers wanted regulation to be more flexible, to maintain burning rotations in the face of growing labor availability constraints and climate change.

It is difficult to generalize how different types of stakeholders perceive each of the scenarios. Partly this is because each category of stakeholder is highly heterogeneous, e.g., sporting interests include land owners, game keepers, and land agents, each with their own views, whereas the conservation group ranges from organizations narrowly focused on conservation, such as the Wildlife Trusts, to the National Trust with its much broader remit, including access. It is also difficult to generalize because the scenarios themselves contain a number of different components. For example, some members of the land management community were in favor of increasing grazing intensity in uplands but would be concerned to see an expansion of arable agriculture (Box 2). Many land managers were happy to see aspects of the extensification scenario (Box 1) that were similar to current practice, including more restoration, but were concerned about the prospect of land abandonment. Similarly, a minority of conservationists favored forms of extensification that might lead to land abandonment, which they referred to as "rewilding", but the majority favored more conservative forms of extensification, similar to current practice. Understandably, the majority of conservationists were concerned about the possibility of any form of intensification in the uplands, if it were to take place at the expense of the habitats they were working to protect and enhance.

There is also an urgent need to consider the implications of policies that prioritize carbon and wildlife (Box 1) for property rights. The majority of UK uplands are currently held in private ownership, but government intervention has created privatestate property regimes for the management of biodiversity, and there are a few "commons" under common property management, mainly in England (Quinn et al. 2010). This complex mix of property regimes are emerging partly in response to the increased recognition that private land provides important public goods and services that need to be managed in the public interest (Quinn et al. 2010). Private-state property regimes might need to expand in reach and influence if uplands are required to provide an ever wider range of ecosystem services to society. Alternatively, existing financial instruments, e.g., agri-environment schemes, or the emergence of schemes based on PES might incentivize private land owners to manage their land for a wider range of ecosystem services than they currently provide (Reed et al. 2011). Whatever happens, it is clear that the emergence of carbon markets for upland restoration will present unique challenges, given the complex and overlapping array of property rights in UK uplands.

\section{Adaptations}

Despite the many current and future changes that uplands face, there are many opportunities to reduce trade-offs and enhance complementarities between different forms of land use and management in UK uplands. Table A1.1 summarizes a wide range of suggestions made for policy and practice by a crosssection of upland researchers and stakeholders from Scotland and England who took part in a series of interviews and focus groups conducted by the Sustainable Uplands project and Glass et al. (2011). Many of the suggestions that could be implemented by land owners and managers have been discussed elsewhere (Glass et al. 2011). Given our focus on understanding likely trade-offs and complementarities between ecosystem services, we focus on policy suggestions, in particular PES.

There is interest from the UK Government (see, for example, Scottish Government 2010, DEFRA 2011) and the European Union (see wider discussion over greening the Common Agricultural Policy) in ways to restructure financial support to provide incentives for more effective management of ecosystem services. There is interest in accessing new, usually private, sources of finance that can monetize and hence incentivize some of the positive externalities of sustainable upland management. There is also interest in using existing agri-environmental payments more efficiently to secure future provision of ecosystem services under different scenarios.

Investment in the restoration of degraded peatlands appears to represent a win-win scenario that could help meet conservation targets while increasing the resilience of peatlands to climate change and mitigating further climate change by reducing greenhouse gas emissions. Payments are already made for many upland ecosystem services through the EU's Rural Development Programme (Pillar II of the Common Agricultural Policy) via the Upland Entry Level Scheme (UELS) in England, Glastir in Wales, and Rural Priorities in Scotland. In some cases, payments for ecosystem services are made through the private sector. There may be opportunities to expand the range of services currently supported by government schemes, and to elicit further engagement with the private sector to pay for some services. 
In addition to climate regulation through carbon sequestration and storage, it may be possible to generate payments for other ecosystem services from uplands. For example, "green water" schemes whereby companies that need clean water pay land managers upstream to conduct activities, e.g., soil and water conservation measures, that improve water quality (e.g., Sadoff and Grey 2002, Emerton and Bos 2004). Such schemes have the potential to be applied to land management activities in uplands like drain and gully blocking (Armstrong et al. 2009) or the revegetation of bare and eroding peats, which can reduce downstream concentrations of particulate and dissolved organic carbon. For example, several water companies are already paying for clean water via changes in peatland management by funding management schemes, e.g., drain blocking or bare peat restoration, which they view to be more cost effective in the long term than spending money on enhanced water treatment.

Many of the cultural ecosystem services provided by uplands focus around activities and values that are hard to monetize. However, "visitor payback" schemes are now emerging that enable visitors to pay for environmental management that supports these services. For example, the scheme, "Our Man at the Top" secures $£ 50 \mathrm{k}$ per year for such work by adding a $£ 2$ surcharge to every week booked by tourists in the Lake District (Reed et al. 2011). Alternatively, there are a range of mechanisms that can broadly be considered under "spatial planning" approaches, that help broker arrangements between developers, landowners, and planning authorities to create and enhance the management of habitats at a landscape scale (Reed et al. 2011).

Markets are also emerging to pay for biodiversity. Habitat banking can be used to purchase biodiversity credits that offset the impacts of development on biodiversity by creating or enhancing habitats elsewhere (Latimer and Hill 2007, Briggs et al. 2009). In Europe, this is partly already enforced through the Habitats Directive and the Bird Directive, which demand like-for-like compensation where development that is of overriding public interest damages important sites for conservation. It may be possible to generate biodiversity credits from the restoration of degraded upland habitats that could be traded to offset damage from development. However, given the relatively high proportion of uplands protected by conservation designations and that offsets must be like-forlike, it is unlikely that there would ever be a large market for credits generated for this purpose.

Although there are many attractions to PES, some significant unresolved challenges remain, such as those associated with realizing "output-based payments" (Engel et al. 2008) or "payment-by-results" (Schwarz et al. 2008) schemes, i.e., those that make payments proportional to the amount of ecosystem service provided. Despite significant advances in recent years, scientific understanding of the complex relationships between ecological and biophysical processes and service provision remains limited (Daily and Matson 2008) and more is known about some services than others. The spatial interconnectedness of ecosystem services in multifunctional landscapes makes it difficult to identify exactly which land managers are responsible for delivering which services. As a consequence, identifying and enforcing who should pay whom, and identifying where property rights lie to underpin this, can be tricky (Kroeger and Casey 2007). Monitoring and verification of the ecosystem services provided in return for payments also presents challenges. The cost of monitoring a wide range of ecosystem services rapidly becomes prohibitive, potentially outweighing the economic efficiencies that such a scheme should theoretically provide (Schwarz et al. 2008). There is a danger that if private PES schemes proliferate in future at local scales without sufficient coordination at a national scale, trade-offs may arise, with benefits from one scheme cancelling out the benefits of another. There is, therefore, an urgent need to consider how PES for a range of ecosystem services could be coordinated in the uplands. Such coordination requires the involvement of natural and social scientists, the former to develop an adequate evidence base on the effects of land management on ecosystem services in different locations and the latter to identify priority ecosystem services and tailor incentives to target their provision.

\section{CONCLUSIONS}

Developing policies that can protect and enhance, rather than compromise the future provision of ecosystem services is an urgent societal challenge, as decision makers attempt to tackle climate change and food security in the context of ongoing demographic and cultural change. Anticipating how policy decisions might lead to trade-offs between ecosystem services may help avoid or manage some of the worst trade-offs and help develop policies that protect and enhance multiple services. By understanding how land use and management affects different ecosystem services, it may be possible to identify the hidden costs and benefits of land management for which society does not pay, and from which land managers do not directly benefit. By paying land managers for the societal benefits of sustainable land management and to reduce the costs to society of less sustainable practices, it may be possible to harness private investment in the future provision of ecosystem services. Such payments for ecosystem services schemes are now proliferating internationally, and are being piloted in the UK through mechanisms established in the UK Government's Department for Environment, Food and Rural Affairs White Paper on the Natural Environment (DEFRA 2011) and via policies in the devolved administrations like the Scottish Government's Land Use Strategy (Scottish Government 2010). However, to ensure that a payment for one 
ecosystem service does not inadvertently compromise the provision of other important services, it is essential to have a spatially explicit understanding of how changes in land use and management in response to policy are likely to affect multiple ecosystem services.

This paper has shown how, with the aid of computer models in close collaboration with decision makers and other stakeholders, it is possible to quantify and map how policy decisions are likely to affect multiple ecosystem services in future. In this way, it is possible to identify potential tradeoffs and complementarities between different ecosystem services, so that policies can be designed to avoid the worst trade-offs and enhance multiple services where possible. In contrast to the use of visualizations and user interfaces, communicating scenarios via film facilitated the integration of local and scientific knowledge and enabled all stakeholders to reach a similar level of understanding so that they could develop adaptations together in response to the research findings.

Two contrasting scenarios were developed through a combination of interviews and discussions during site visits with stakeholders, literature review, conceptual modeling, and process-based computer models, using the Dark Peak of the Peak District National Park in the UK as a case study. Both scenarios led to a range of costs and benefits to society, many of which have not currently been paid. In places where extensification leads to a significant reduction in managed burning and grazing or land abandonment, changes in vegetation type and structure could compromise a range of species that are important for conservation, while compromising provisioning services, notably sheep and Red Grouse in the Dark Peak of the Peak District, the amenity value for those who currently value the open nature of the landscape, and increasing the risk of carbon in peat soils being released through wildfire. However, where extensification leads to the restoration of peatlands damaged by former intensive management, i.e., blocking drainage ditches and revegetating bare/eroding peat, there would be an increase in carbon sequestration and storage, with a number of cobenefits, which could counter the loss of habitats and species elsewhere in the landscape.

In the second scenario, land use and management was significantly intensified, through increased livestock grazing and bringing limited areas into arable production, in response to concerns over the UK's self-sufficiency in food. This led to benefits for certain provisioning services, mainly food production, that were offset by a wide range of negative consequences for most other ecosystem services, notably carbon storage, water quality, and the loss of important habitats and species of conservation concern. A reduction in the abundance of a range of such species was a negative consequence of both scenarios, and as such may be a flashpoint for future conflict in UK uplands.

As these scenarios depict, the provision of ecosystem services is likely to change over time in response to a range of different policy and environmental drivers. Ecosystem services will also change in response to the changing demands and preferences of society, which are far harder to anticipate. Society needs to be aware that its current use of ecosystem services might compromise its ability to realize future uses (Hubacek et al. 2009). For example, peatlands can be extracted for horticulture and fuel, but historic extraction of peat has compromised the ability of these environments to sequester carbon and provide for wildlife habitats, water purification, and run-off attenuation. As society's needs and priorities change, new ecosystem services may emerge, causing shifts in the way existing ecosystem services are prioritized (Hubacek et al. 2009). For this reason, it is essential to further develop spatially explicit models that can track how ecosystem services might change over time, further integrating models to understand how such changes might influence land manager decisions in future, and incorporating a wider range of ecosystem services.

This paper has highlighted the need to develop models in close collaboration with decision makers and other stakeholders, if they are to depict scenarios of real concern to those who are likely to use the model outputs. Films and other media (see Appendix) were used as a way of illustrating narratives based on a combination of model outputs and qualitative insights from interviews and site visits, rather than focusing on the development of a user interface for the models that are likely to be little used, e.g., the NELUP model (O'Callaghan 1995). In this way, it was possible to engage as wide an audience as possible with research findings and facilitate discussion with stakeholders about adaptive options to minimize trade-offs and enhance the provision of multiple ecosystem services under very different future conditions. By preparing for a wide range of possible futures in this way, it may be possible for decision makers to act rapidly and effectively in the face of unpredictable future change. As Malcolm X said, "the future belongs to those who prepare for it today."

Responses to this article can be read online at: http://www.ecologyandsociety.org/issues/responses. $\mathrm{php} / 4924$

\section{Acknowledgments:}

We thank all stakeholders for their participation and in particular the Moors for the Future Partnership and the Heather Trust for their engagement as part of the Sustainable 
Uplands consortium. This paper was originally written as a supplementary background paper to the Scottish Government's Rural Land Use Study ( "Realising the Potential Contributions of Scotland's Rural Land to Delivering Sustainable Economic Growth"). A small amount of review material was compiled originally for a DEFRA report on "Barriers and Opportunities to the Use of Payments for Ecosystem Services." Mark Reed is also funded by a British Academy Research Development Award. The Sustainable Uplands project has been funded in three phases: under the first phase (funded by RELU from 2005-2009) the project was co-ordinated by Klaus Hubacek (Principal Investigator [PI]) and Mark Reed (Project Manager); under the second phase (funded by ESRC from 2009-2010) the project was coordinated by Joe Holden (co-PI) and Mark Reed (co-PI); under the third phase (funded by RELU from 2010-2012) the project is co-ordinated by Mark Reed (PI). The authors are also grateful for funding from NERC's Valuing Nature Network.

\section{LITERATURE CITED}

Alcamo, J., D. van Vuuren, C. Ringler, W. Cramer, T. Masui, J. Alder, and K. Schulze. 2005. Changes in nature's balance sheet: model-based estimates of future worldwide ecosystem services. Ecology and Society 10(2): 19. [online] URL: http:// www.ecologyandsociety.org/vol10/iss2/art19/

Armstrong, A., J. Holden, P. Kay, M. Foulger, S. Gledhill, A. T. McDonald, and A. Walker 2009. Drain blocking techniques on blanket peat: a framework for best practice. Journal of Environmental Management 90:3512-3519. http://dx.doi. org/10.1016/j.jenvman.2009.06.003

Balmford, A., A. S. L. Rodrigues, M. Walpole, P. ten Brink, M. Kettunen, L. Braat, and R. de Groot. 2008. The economics of biodiversity and ecosystems: scoping the science. European Commission, Cambridge, UK.

Bonn, A., J. Holden, M. Parnell, F. Worrall, P. J. Chapman, C. D. Evans, Termansen, M., N. Beharry-Borg, M. C. Acreman, E. Rowe, B. Emmett, and A. Tsuchiya. 2010. Ecosystem services of peat - phase 1: Project code SP0572. Department for Environment, Food and Rural Affairs, London, UK.

Bonn, A., M. Rebane, and C. Reid. 2009. Ecosystem services: a new rationale for conservation of upland environments. Pages 448-74 in A. Bonn, T. Allott, K. Hubacek, J. Stewart, editors. Drivers of environmental change in uplands. Routledge, London, UK.

Braden, S. 1999. Using video for research and representation: basic human needs and critical pedagogy. Journal of Environmental Media 24:117-129. http://dx.doi. org/10.1080/1358165990240204
Briggs, B. D. J., D. A. Hill, and R. Gillespie. 2009. Habitat banking - how it could work in the UK. Journal for Nature Conservation 17:112-122. http://dx.doi.org/10.1016/j.jnc.2008.12.006

Burt, T. P., and J. Hanwell. 1992. Land of many uses. Geography Review 6:2-8.

Chapman, D. S., A. Bonn, W. E. Kunin, and S. J. Cornell. 2010. Random forest characterization of upland vegetation and management burning from aerial imagery. Journal of Biogeography 37:37-46. http://dx.doi.org/10.1111/

j.1365-2699.2009.02186.x

Chapman, D. S., S. J. Cornell, and W. E. Kunin. $2009 b$. Interactions between harvesting, noise and territoriality in a model of Red Grouse population cycles. Journal of Animal Ecology 78:476-484. http://dx.doi.org/10.1111/ j.1365-2656.2008.01496.x

Chapman, D. S., M. Termansen, C. H. Quinn, N. Jin, A. Bonn, S. J. Cornell, E. D. G. Fraser, K. Hubacek, W. E. Kunin, and M. S. Reed. 2009a. Modelling the coupled dynamics of moorland management and upland vegetation. Journal of Applied Ecology 46:278-288. http://dx.doi.org/10.1111/ j.1365-2664.2009.01618.x

Christie, M., T. Hyde, R. Cooper, I. Fazey, P. Dennis, J. Warren, S. Colombo, and N. Hanley. 2010. Economic valuation of the benefits of ecosystem services delivered by the UK Biodiversity Action Plan, Defra Project SFFSD 0702. Department for Environment, Food and Rural Affairs, London, UK.

Daily, G. C., and P. A. Matson. 2008. Ecosystem services: from theory to implementation. Proceedings of the National Academy of Sciences of the United States of America 105:9455-9456. http://dx.doi.org/10.1073/pnas.0804960105

Deary, H. A. 2012. Rewilding in 'Monarch of the Glen' county: a critical and applied review of wild land management practices in the Scottish Highlands. Centre for Sustainability, University of Otago, Dunedin, New Zealand.

Department of Environment, Food and Rural Affairs (DEFRA). 2011. The natural choice: securing the value of nature. The Natural Environment White Paper, DEFRA, London, UK.

Dougill, A., E. D. G. Fraser, J. Holden, K. Hubacek, C. Prell, M. S. Reed, S. Stagl, and L. C. Stringer. 2006. Learning from doing participatory rural research: lessons from the Peak District National Park. Journal of Agricultural Economics 57:259-275. http://dx.doi.org/10.1111/j.1477-9552.2006.00051. $\underline{\mathrm{X}}$

Eden, C., and F. Ackermann. 1998. Making strategy: the journey of strategic management. Sage, London, UK. 
Egoh, B. N., B. Reyers, J. Carwardine, M. Bode, P. J. O'Farrell, K. A. Wilson, H. P. Possingham, M. Rouget, W. De Lange, D. M. Richardson, and R. M. Cowling. 2010. Safeguarding biodiversity and ecosystem services in the Little Karoo, South Africa. Conservation Biology 24(4):1021-1030. http://dx.doi. org/10.1111/j.1523-1739.2009.01442.X

Emerton, L., and E. Bos. 2004. Value - counting ecosystems as water infrastructure. International Union for Conservation of Nature, Gland, Switzerland. http://dx.doi.org/10.2305/ IUCN.CH.2004.WANI.3.en

Engel, S., S. Pagiola, and S. Wunder, 2008. Designing payments for environmental services in theory and practice: an overview of the issues. Ecological Economics 65:663-674. http://dx.doi.org/10.1016/j.ecolecon.2008.03.011

English Nature. 2003. England's best wildlife and geological sites: the condition of sites of special scientific interest in England in 2003. English Nature, Sheffield, UK.

Foresight. 2011. The future of food and farming: challenges and choices for global sustainability. Final Project Report. The Government Office for Science, London, UK.

Glaser, B. G., and A. Strauss. 1967. Discovery of grounded theory: strategies for qualitative research. Aldine, Chicago, Illinois, USA.

Glass, J. H., A. J. Scott, and M. F. Price. 2011. Developing a sustainability assessment tool for upland estates. Pages 425-428 in S. J. Marrs, S. Foster, C. Hendrie, E. C. Mackey, and D. B. A. Thompson, editors. The changing nature of Scotland. Scottish Natural Heritage, Edinburgh, UK.

Holden, J., L. Shotbolt, A. Bonn, T. P. Burt, P. J. Chapman, A. J. Dougill, E. D. G. Fraser, K. Hubacek, B. Irvine, M. J. Kirkby, M. S. Reed, C. Prell, S. Stagl, L. C. Stringer, A. Turner, and F. Worrall. 2007. Environmental change in moorland landscapes. Earth-Science Reviews 82:75-100. http://dx.doi. org/10.1016/j.earscirev.2007.01.003

Hubacek, K., N. Beharry-Borg, A. Bonn, T. P. Burt, J. Holden, F. Ravera, M. S. Reed, L. C. Stringer, and D. Tarrasón. 2009. Ecosystem services in dynamic and contested landscapes: the case of UK uplands. In M. Winter and M. Lobley, editors. Land use and management: the new debate. Earthscan, London, UK.

Hubacek, K., and M. S. Reed. 2009. Lessons learned from a computer-assisted participatory planning and management process in the Peak District National Park, England. Pages 189-202 in C. Allen and G. Stankey, editors. Adaptive environmental management: a practical guide. Springer, Dorcrecht, The Netherlands. http://dx.doi.org/10.1007/978-$\underline{1-4020-9632-7 \quad 10}$
Intergovernmental Panel on Climate Change (IPCC). 2000. IPCC special report: emissions scenarios. Cambridge University Press, Cambridge, UK.

Jin, N., D. Chapman, and K. Hubacek. 2009. Adaptive landuse management in dynamic ecological system. Pages 152-161 in M. Giacobini, A. Brabazon, S. Cagnoni, G. Di Caro, A. Ekárt, A. Esparcia-Alcázar, M. Farooq, A. Fink, and P. Machado, editors. Applications of evolutionary computing. Springer, Berlin, Germany.

Kindon, S. 2003. Participatory video in geographic research: a feminist practice of looking? Area 35:142-153. http://dx.doi. org/10.1111/1475-4762.00236

Kirkby, M. J., B. J. Irvine, R. J. A. Jones, G. Govers, and PESERA Team. 2008. The PESERA coarse scale erosion model for Europe. I. - Model rationale and implementation. European Journal of Soil Science 59:1293-1306. http://dx.doi. org/10.1111/j.1365-2389.2008.01072.x

Kroeger, T., and F. Casey. 2007. An assessment of marketbased approaches to providing ecosystem services on agricultural lands. Ecological Economics 64:321-332. http:// dx.doi.org/10.1016/j.ecolecon.2007.07.021

Latimer, W., and D. Hill 2007. Mitigation banking: securing no net loss to biodiversity? A UK perspective. Planning Practice and Research 22:155-175. http://dx.doi. org/10.1080/02697450701584337

Mensonides, M., B. Huisman, and V. Dignum. 2008. Towards agent-based scenario development for strategic decision support. Pages 53-72 In Proceedings of the 8th International Bi-Conference on Agent-Oriented Information Systems. Springer-Verlag, Berlin, Germany. http://dx.doi. org/10.1007/978-3-540-77990-2 4

Millennium Ecosystem Assessment (MEA). 2005. Ecosystems and human well-being: synthesis. Island Press, Washington, D.C., USA.

Morris, J., E. Audsley, I. A. Wright, J. McLeod, K. Pearn, A. Angus, and S. Rickard, 2005. Agricultural futures and implications for the environment. Defra Research Project IS0209, Cranfield University, Cranfield, UK.

Nakicenovic, N., A. Grübler, and A. McDonald, editors. 1998. Global energy perspectives. Cambridge University Press, Cambridge, UK.

O'Callaghan, J. R. 1995. NELUP: an introduction. Journal of Environmental Planning and Management 38:5-20. http://dx. doi.org/10.1080/09640569513084

Office for National Statistics. 2003. Census 2001: $C D$ supplement to the National report for England and Wales and 
key statistics for local authorities in England and Wales. Office for National Statistics, London, UK.

Opdam, P., R. Foppen, and C. Vos. 2001. Bridging the gap between ecology and spatial planning in landscape ecology. Landscape Ecology 16:767-779. http://dx.doi.org/10.1023/ A:1014475908949

Peak District National Park Authority. 2004. State of the park report. Peak District National Park Authority, Bakewell, UK. [online] URL: http://www.peakdistrict.gov.uk/publications/ sopr

Pearce-Higgins, J. W., C. M. Beale, J. Wilson, and A. Bonn. 2006. Analysis of moorland breeding bird distribution and change in the Peak District. Report No. 11, Moors for the Future, Edale, UK.

Prell, C., K. Hubacek, C. Quinn, and M. S. Reed. 2008. 'Who's in the network?' When stakeholders influence data analysis. Systemic Practice and Action Research 21:443-458. http://dx. doi.org/10.1007/s11213-008-9105-9

Prell, C., K. Hubacek, M. S. Reed, T. P. Burt, J. Holden, N. Jin, C. Quinn, and J. Sendzimir. 2007. If you have a hammer everything looks like a nail: traditional versus participatory model building. Interdisciplinary Science Reviews 32:263-282.

Prell, C., M. S. Reed, and K. Hubacek. 2009. Stakeholder analysis and social network analysis for natural resource management. Society \& Natural Resources 22:501-518. http:// dx.doi.org/10.1080/08941920802199202

Prell, C., M. Reed, L. Racin, and K. Hubacek. 2010. Competing structure, competing views: the role of formal and informal social structures in shaping stakeholder perceptions. Ecology and Society 15(4): 34. [online] URL: http://www. ecologyandsociety.org/vol15/iss4/art34/

Quinn, C. H., E. D. G. Fraser, K. Hubacek, and M. S. Reed. 2010. Property rights in UK uplands and the implications for policy and management. Ecological Economics 69:1355-1363. http://dx.doi.org/10.1016/j.ecolecon.2010.02.006

Raymond, C. M., I. Fazey, M. S. Reed, L. C. Stringer, G. M. Robinson, and A. C. Evely. 2010. Integrating local and scientific knowledge for environmental management. Journal of Environmental Management 91:1766-1777. http://dx.doi. org/10.1016/j.jenvman.2010.03.023

Reed, M. S., A. Bonn, K. Broad, P. Burgess, I. R. Fazey, E. D. G. Fraser, K. Hubacek, D. Nainggolan, P. Roberts, C. H. Quinn, L. C. Stringer, S. Thorpe, D. D. Walton, F. Ravera, and S. Redpath. In press. Participatory scenario development for environmental management: a methodological framework. Journal of Environmental Management.
Reed, M. S., A. Bonn, W. Slee, N. Beharry-Borg, J. Birch, I. Brown, T. P. Burt, D. Chapman, P. J. Chapman, G. D. Clay, S. J. Cornell, E. D. G. Fraser, J. H. Glass, J. Holden, J. A. Hodgson, K. Hubacek, B. Irvine, N. Jin, M. J. Kirkby, W. E. Kunin, O. Moore, D. Moseley, C. Prell, M. F. Price, C. H. Quinn, S. Redpath, C. Reid, S. Stagl, L. C. Stringer, M. Termansen, S. Thorp, W. Towers, and F. Worrall. 2009. The future of the uplands. Land Use Policy 26:S204-S216. http:// dx.doi.org/10.1016/j.landusepol.2009.09.013

Reed, M. S., S. Buckmaster, A. P. Moxey, C. Keenleyside, I. Fazey, A. Scott, K. Thomson, S. Thorp, R. Anderson, I. Bateman, R. Bryce, M. Christie, J. Glass, K. Hubacek, C. H. Quinn, G. Maffey, A. Midgely, G. Robinson, L. C. Stringer, P. Lowe, and R. Slee. 2011. Policy options for sustainable management of UK peatlands. IUCN Technical Review 12, International Union for Conservation of Nature UK Peatland Programme, Edinburgh, UK.

Sadoff, C. W., and D. Grey. 2002. Beyond the river: the benefits of cooperation on international rivers. Water Policy 4:389-403. http://dx.doi.org/10.1016/S1366-7017(02)00035-1

Schwarz, G., A. Moxey, D. McCracken, S. Huband, and R. Cummins. 2008. An analysis of the potential effectiveness of a payment-by-results approach to the delivery of environmental public goods and services supplied by agrienvironment schemes. Land Use Policy Group, Peterborough, UK.

Scottish Government. 2010. Getting the best from our land: a draft land use strategy for Scotland: Consultation: for discussion and feedback. Scottish Government, Edinburgh, UK.

Turner, R. K., and G. C. Daily. 2008. The ecosystem services framework and natural capital conservation. Environmental and Resource Economics 39(1):25-35. http://dx.doi. org/10.1007/s10640-007-9176-6

van der Wal, R., A. Bonn, D. Monteith, M. S. Reed, K. Blackstock, N. Hanley, D. Thompson, M. Evans, I. Alonso, with T. Allot, H. Armitage, N. Beharry-Borg, J. Glass, S. Johnson, J. McMorrow, L. Ross, R. Pakeman, S. Perry, and D. Tinch. 2011. Mountains, moorlands and heathlands. Chapter 5 in UK national ecosystem assessment: technical report. United Nations Environment Programme World Conservation Monitoring Centre (UNEP-WCMC), Cambridge, UK.

Vermeulena, S. J., P. K. Aggarwal, A. Ainslie, C. Angelone, B. M. Campbell, A. J. Challinor, J. W. Hansen, J. S. I. Ingram, A. Jarvis, P. Kristjanson, C. Lau, G. C. Nelson, P. K. Thornton, and E. Wollenberg. 2012. Options for support to agriculture and food security under climate change. Environmental 
Science \& Policy 15:136-144 . http://dx.doi.org/10.1016/j. envsci.2011.09.003

White, S. A. 2003. Participatory video: images that transform and empower. Sage, London, UK.

Worrall, F., T. Burt, J. Adamson, M. S. Reed, J. Warburton, A. Armstrong, and M. Evans. 2007. Predicting the future carbon budget of an upland peat catchment. Climatic Change 85:139-158. http://dx.doi.org/10.1007/s10584-007-9300-1

Worrall, F., M. G. Evans, A. Bonn, M. S. Reed, D. Chapman, and J. Holden. 2009. Can carbon offsetting pay for upland ecological restoration? Science of the Total Environment 408:26-36. http://dx.doi.org/10.1016/j.scitotenv.2009.09.022 


\section{Appendix}

Item 1: Illustrated children's fairytale

Item 2: Music video

Item 3: Table 1 (below)

Table 1: Opportunities to reduce trade-offs and enhance complementarities between different forms of land use and management in UK uplands (results compiled from the Sustainable Uplands Project site visits and expert workshop and the Sustainable Estates project (Glass et al., 2011) (from Reed et a1.., 2009).

\begin{tabular}{|c|c|c|c|}
\hline Themes & Adaptation strategies & Example & Source* \\
\hline \multirow{4}{*}{$\begin{array}{l}\text { Restructured } \\
\text { financial } \\
\text { support: an } \\
\text { ecosystem } \\
\text { goods and } \\
\text { services } \\
\text { approach }\end{array}$} & \multirow{2}{*}{$\begin{array}{l}\text { Provide incentives for } \\
\text { management of } \\
\text { ecosystem goods and } \\
\text { services }\end{array}$} & $\begin{array}{l}\text { Use financial incentives e.g. to ensure the appropriate } \\
\text { combination of moorland burning and grazing }\end{array}$ & $a, b, c$ \\
\hline & & $\begin{array}{l}\text { Include carbon storage/management payments in } \\
\text { Environmental Stewards hip grant schemes }\end{array}$ & b,c \\
\hline & Regulate management & Penalise inappropriate or damaging management outcomes & $\mathrm{a}, \mathrm{c}$ \\
\hline & $\begin{array}{l}\text { Develop innovative } \\
\text { tax/trading systems }\end{array}$ & $\begin{array}{l}\text { Individual 'carbon allocations' and collection of 'carbon tax' or } \\
\text { 'offsetting schemes' }\end{array}$ & $a, b$ \\
\hline \multirow{5}{*}{$\begin{array}{l}\text { Resilient rural } \\
\text { businesses } \\
\text { that can } \\
\text { withstand } \\
\text { future shocks }\end{array}$} & $\begin{array}{l}\text { Plan long-tem } \\
\text { management visions }\end{array}$ & $\begin{array}{l}\text { Draw up long-term, integrated spatial plans for future change } \\
\text { e.g. rewetting peat soils, woodland regeneration etc. }\end{array}$ & $a, b, c$ \\
\hline & \multirow{3}{*}{$\begin{array}{l}\text { Diversify income } \\
\text { streams and add value } \\
\text { to products }\end{array}$} & $\begin{array}{l}\text { Focus on quality rather than quantity e.g. specialis ed local } \\
\text { food products, diversify lives tock, create tourism opportunities }\end{array}$ & $a, b, c$ \\
\hline & & $\begin{array}{l}\text { Inject more cash into non-agricultural economic activity to } \\
\text { maintain upland economies (private and public sources) }\end{array}$ & $a, b, c$ \\
\hline & & $\begin{array}{l}\text { Develop biomass and carbon storage opportunities e.g. small } \\
\text { scale wood pellet enterprises, willow plantations etc }\end{array}$ & b, c \\
\hline & Encourage innovation & $\begin{array}{l}\text { Exemplify innovative land managers that make changes rather } \\
\text { than allowing change to dictate practices }\end{array}$ & $a, b, c$ \\
\hline \multirow{7}{*}{$\begin{array}{l}\text { Integrated } \\
\text { management } \\
\text { that delivers } \\
\text { environmental } \\
\text { and other } \\
\text { benefits }\end{array}$} & \multirow{3}{*}{$\begin{array}{l}\text { Environmental risk } \\
\text { management }\end{array}$} & $\begin{array}{l}\text { Wildfire risk control, ensure designated sites are in favourable } \\
\text { condition, maintain viable populations of appropriate species }\end{array}$ & $\mathrm{a}, \mathrm{c}$ \\
\hline & & $\begin{array}{l}\text { Ecological restoration projects e.g. gully and grip blocking to } \\
\text { reduce erosion, riparian improvements to mitigate flooding }\end{array}$ & $\mathrm{a}, \mathrm{c}$ \\
\hline & & $\begin{array}{l}\text { Reduce impacts of upland management resource use e.g. } \\
\text { increase energy efficiency/sustainable building design }\end{array}$ & c \\
\hline & \multirow{2}{*}{$\begin{array}{l}\text { Link into local } \\
\text { communities }\end{array}$} & $\begin{array}{l}\text { Release land for development and play a role in housing } \\
\text { provision to reduce upland depopulation }\end{array}$ & $\mathrm{c}$ \\
\hline & & Develop local food markets and encourage self-sufficiency & $\mathrm{c}$ \\
\hline & $\begin{array}{l}\text { Manage increasing } \\
\text { upland recreation }\end{array}$ & $\begin{array}{l}\text { Manage footpaths and access points to reduce impacts, } \\
\text { increase ranger provision for education and monitoring }\end{array}$ & $\mathrm{a}, \mathrm{c}$ \\
\hline & $\begin{array}{l}\text { Manage visual impacts } \\
\text { of management }\end{array}$ & $\begin{array}{l}\text { Heather burning, grazing levels, tree planting, bracken control, } \\
\text { renewable energy developments, cultural heritage etc. }\end{array}$ & $\mathrm{b}, \mathrm{c}$ \\
\hline \multirow{7}{*}{$\begin{array}{l}\text { Productive } \\
\text { knowledge } \\
\text { generation and } \\
\text { exchange }\end{array}$} & \multirow{2}{*}{$\begin{array}{l}\text { Join up thinking and } \\
\text { dialogue among } \\
\text { stakeholders }\end{array}$} & $\begin{array}{l}\text { Find common ground between interest groups and encourage } \\
\text { understanding of the needs and wants of different users }\end{array}$ & $a, c$ \\
\hline & & $\begin{array}{l}\text { Partner across the region e.g. develop habitat linkages, } \\
\text { manage increases in recreational activities etc. }\end{array}$ & $a, b, c$ \\
\hline & Share best practice & $\begin{array}{l}\text { Exemplify successful management practices e.g. diss eminate } \\
\text { moorland restoration techniques/technology }\end{array}$ & $a, b, c$ \\
\hline & $\begin{array}{l}\text { Raise public awareness } \\
\text { of upland management }\end{array}$ & $\begin{array}{l}\text { Educate about the multiple uses of moorlands and the role of } \\
\text { managers/gamekeepers/farmers/rangers }\end{array}$ & $\mathrm{a}$ \\
\hline & \multirow{3}{*}{$\begin{array}{l}\text { Improve scientific } \\
\text { evidence, } \\
\text { understanding and } \\
\text { monitoring }\end{array}$} & $\begin{array}{l}\text { More research e.g. relations hip between water quality and } \\
\text { local conditions; the effects of grouse moor management on } \\
\text { ecosystem services }\end{array}$ & $\mathrm{a}$ \\
\hline & & Integrate local experience and knowledge into management & $\mathrm{a}, \mathrm{c}$ \\
\hline & & $\begin{array}{l}\text { Well-designed, structured and standardis ed monitoring e.g. } \\
\text { changes in moorland diversity/restoration progress }\end{array}$ & $\mathrm{a}, \mathrm{c}$ \\
\hline
\end{tabular}


* $\quad a=$ Sustainable Uplands project site visits, Peak District National Park and Nidderdale AONB, summer 2008

$b=$ Battle of the experts workshop, RELU Future of Rural Land Use event, 4 June 2009 C= Sustainable Estates Delphi survey, Scotland (Glass et al. 2011) 